Revista Eletrônica Geografar, Curitiba, v. 2, Resumos do VI Seminário Interno de Pós-Graduação em Geografia, p. 33-33. Junho/2007

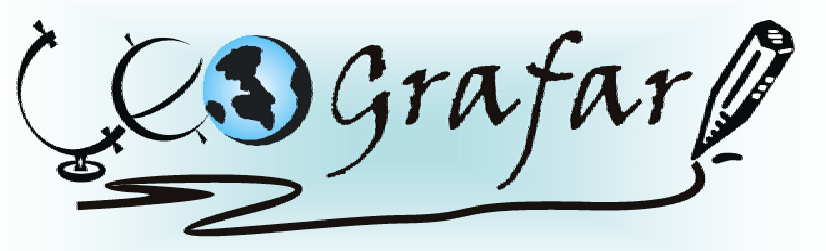

Revista Eletrônica do Programa de Pós-Graduação em Geografia - UFPR

\title{
A RESSIGNIFICAÇÃO DAS REPRESENTAÇÕES E IMAGENS DA PAISAGEM NATURAL NA DIVERSIDADE SOCIAL E CULTURAL DAS COMUNIDADES LITORÂNEAS DO PARANÁ: SUBSÍDIOS AO DESENVOLVIMENTO URBANO SUSTENTÁVEL
}

\author{
HELENA MIDORI KASHIWAGI ${ }^{1}$
}

No litoral do Paraná ainda existem diversas comunidades que se utilizam dos recursos naturais para a sua sobrevivência, dentre elas, as comunidades indígenas, as rurais e as de pescadores. Durante muito tempo o modo de viver, as tradições, a cultura dessas comunidades são repassadas de geração em geração e o respeito pelo bem natural tem sido a principal herança. Percebe-se que esta herança foi se transformando à medida que a cidade foi se desenvolvendo e a tecnologia substituindo o ser humano. A paisagem natural dá lugar ao construído e este processo de transformação urbana e ambiental tem reflexos impactantes sobre as comunidades de pescadores, as quais foram forçosamente relocadas para áreas periféricas da cidade, distantes do seu meio de sobrevivência, o mar. Estas comunidades tornam-se foco desta pesquisa, pois armazenam em suas memórias importantes registros da paisagem local. Neste sentido, ao fazermos o recorte geográfico, tendo como objeto de pesquisa o Município de Matinhos, descobrimos a grande incidência de "mulheres pescadoras". Este fato despertou-nos o interesse de se compreender como elas percebem o meio natural e levou-nos a alguns questionamentos: Como elas constroem as territorialidades no mar e na terra? Esta compreensão de espacialidade é uma herança repassada de mãe para filha? Quais são as suas percepções sobre a paisagem? Quais são os referenciais sígnicos utilizados em seu cotidiano? Neste contexto, o trabalho empírico consistido de entrevistas e mapas mentais se fundamentará nos aportes teóricos e metodológicos da Geografia Humanística, em sua vertente fenomenológica, adotando-se a metodologia desenvolvida por KOZEL (2001) para interpretação dos mapas. Esta pesquisa visa desvendar, por meio de recorte de gênero e geração, os elementos sígnicos que consolidam a história de um lugar e a caracterização da apropriação urbana da cidade.

Palavras-chave: Paisagem, Desenvolvimento, Fenomenologia.

1Doutoranda em Geografia - UFPR - email: helenamidori@ufpr.br Orientadora: SALETE KOZEL 